\title{
HUBUNGAN LINGKAR PINGGANG, ASUPAN ZAT GIZI, DAN AKTIVITAS FISIK DENGAN KEPADATAN TULANG PADA WANITA USIA 30-50 TAHUN
}

\author{
Zenita Novarinda, Nuryanto*) \\ Program Studi Ilmu Gizi Fakultas Kedokteran Universitas Diponegoro \\ Jl.Dr.Sutomo No.18, Semarang, Telp (024) 8453708, Email : gizifk@undip.ac.id
}

\begin{abstract}
Background : Central obesity prevalence are increase in women. Women known have higher risk of osteoporosis than men. Waist circumference, nutrient intake, and physical activity are factors affecting bone density. Waist circumference is marker of central obesity. The aim of this study is to determine the relationship between waist circumference, nutrient intake, and physical activity with bone density in women age 30-50 years old.

Methods :Research held on Bulustalan and Sampangan, Semarang in August and September 2014. Design of this study is cross-sectional with 44 women aged 30-50 years old. The data taken were waist circumference, protein, calcium, and vitamin D intake, physical activity, and bone density score. Bivariat analysis was using rank Spearman and Pearson test and multivariate analysis was using double linier regression test.

Results : There are $36.4 \%$ subject are osteopenia. The average subjects have moderate physical activity (996.82 MET.minute/week). The average protein, calcium, and vitamin D intake are $86.50 \%, 50.60 \%$, and $28.37 \%$ from nutritional adequacy. There are no correlation between vitamin $D$ intake and physical activity with bone density $(p>0,05)$. However, there are significant correlation between waist circumference $(p=0.026)$, protein intake $(p=0.046)$ and calcium intake $(p=0.038)$ with bone density $(p<0,05)$. After regression analysis, calcium intake give the most influence to bone density.

Conclusion : There are significant negative correlation between waist circumference with bone density and significant positive correlation between protein and calcium intake with bone density in women age 30-50 years old. There are no significant correlation between vitamin D intake and physical activity with bone density in women age 30-50 years old.
\end{abstract}

Keywords : bone density; waist circumference; nutrient intake; physical activity

\section{ABSTRAK}

LatarBelakang : Prevalensi obesitas sentral pada wanita di Indonesia semakin meningkat. Wanita diketahui memiliki risiko osteoporosis yang tinggi dibanding laki-laki. Lingkar pinggang, asupan zat gizi,dan aktivitas fisik adalah faktor-faktor yang mempengaruhi kepadatan tulang. Lingkar pingang merupakan indikator dari obesitas sentral. Tujuan penelitian ini adalah untuk mengetahui hubungan lingkar pinggang, asupan zat gizi, dan aktivitas fisik dengan kepadatan tulang pada wanita usia 30-50 tahun.

Metode :Penelitian dilaksanakan di Kelurahan Bulustalan dan Sampangan Semarang pada bulan Agustus dan September 2014. Desain penelitian cross-sectional dengan subyek 44 wanita usia 30-50 tahun. Data yang diambil adalah data lingkar pinggang, asupan protein, kalsium, vitamin D, tingkat aktivitas fisik, dan kepadatan tulang. Analisis bivariat dengan uji rank Spearman dan uji Pearson. Analisis multivariat menggunakan uji regresi linier ganda.

Hasil : Terdapat $36.4 \%$ subyek yang mengalami osteopenia. Rata-rata aktivitas fisik subyek dalam kategori sedang (996.82 MET.menit/minggu). Rerata tingkat kecukupan protein, kalsium, dan vitamin D yaitu 86.50\%, 50.60\%, dan $28.37 \%$ dari kebutuhan. Vitamin D dan aktivitas fisik tidak berhubungan dengan kepadatan tulang $(p>0,05)$. Terdapat hubungan bermakna antara lingkar pinggang $(p=0.026)$, asupan protein $(p=0.046)$, dan $\mathrm{kalsium}$ $(p=0.038)$ dengan kepadatan tulang $(p<0.05)$. Pada analisis regresi linier ganda, asupan kalsium memberi pengaruh paling besar terhadap kepadatan tulang.

Kesimpulan : Terdapat hubungan negatif yang bermakna antara lingkar pinggang dengan kepadatan tulang dan hubungan positif yang bermakna antara asupan protein dan kalsium dengan kepadatan tulang. Tidak terdapat hubungan yang bermakna antara asupan vitamin D dan aktivitas fisik dengan kepadatan tulang.

Kata Kunci : kepadatan tulang; lingkar pinggang; asupan zat gizi; aktivitas fisik

\section{PENDAHULUAN}

Kepadatan tulang tidak normal merupakan kondisi yang dijadikan sebagai acuan untuk memprediksi terjadinya osteopenia dan osteoporosis. $^{1}$ Osteopenia merupakan tanda terjadinya osteoporosis yang diawali dengan rendahnya kepadatan tulang, apabila berlangsung dalam waktu lama dapat mengakibatkan menurunnya kekuatan tulang sehingga terjadi osteoporosis. $^{2}$ Beberapa faktor yang mempengaruhi kepadatan tulang diantaranya lemak abdominal, asupan zat gizi dan aktivitas

\footnotetext{
${ }^{*}$ Penulis Penanggungjawab
} 
fisik. ${ }^{1,3}$ Osteoporosis dan obesitas abdominal merupakan 2 penyakit dengan prevalensi tinggi pada wanita. $^{2}$

Penelitian yang dilakukan di Puerto Rico tahun 2011 menyebutkan bahwa lemak abdominal berhubungan dengan kepadatan tulang yang lebih rendah pada orang dewasa. ${ }^{3}$ Penelitian lain yang dilakukan di Brazil tahun 2013 pada anak-anak dan remaja obesitas juga menunjukan hubungan negatif antara lemak viseral dan kepadatan tulang. ${ }^{4}$ Penelitian dengan subyek remaja perempuan di Amerika Serikat tahun 2010 menunjukan bahwa lemak viseral merupakan prediktor negatif kepadatan tulang. Subyek dengan lemak viseral tinggi memiliki kepadatan tulang yang rendah. ${ }^{5}$ Lemak abdominal merupakan indikator obesitas sentral yang dapat diukur dengan pengukuran lingkar pinggang. Lemak viseral adalah jaringan lemak yang terletak pada bagian intra abdominal di sekitar organ abdomen yang merupakan indikator obesitas sentral. ${ }^{6}$

Lemak viseral lebih banyak memproduksi sitokin proinflamasi dibanding lemak subkutan. ${ }^{7}$ Tingginya produksi sitokin proinflamatori seperti IL-6 dan TNF- $\alpha$ berkaitan dengan kepadatan tulang yang rendah dan risiko patah tulang karena sitokin proinflamatori tersebut dapat meningkatkan aktivitas osteoklas. ${ }^{8}$ C-Reactive Protein (CRP) yang merupakan reaktan fase akut juga berkaitan penurunan kepadatan tulang dengan meningkatkan aktivitas dan produksi osteoklas. ${ }^{9}$ Lingkar pinggang yang besar berkaitan dengan nilai CRP yang tinggi. ${ }^{10}$ Obesitas sentral berhubungan dengan penurunan konsentrasi adiponektin. ${ }^{11}$ Adiponektin diketahui dapat meningkatkan massa tulang dengan menekan aktivitas osteoklas dan meningkatkan aktivitas osteoblas. Selain itu, serum osteocalcin, protein yang meregulasi pembentukan tulang juga memiliki hubungan negatif dengan lemak viseral. ${ }^{12}$

Aktivitas fisik dan asupan zat gizi berupa protein, kalsium, dan vitamin $\mathrm{D}$ juga berpengaruh terhadap kepadatan tulang secara langsung. Aktivitas fisik dapat mengurangi risiko osteoporosis dan menunda penuruan kepadatan tulang. Sebuah penelitian menunjukkan bahwa aktivitas fisik yang tinggi memiliki efek yang baik bagi tulang pada wanita premenopause. ${ }^{13}$ Selain aktivitas fisik, asupan kalsium, dan vitamin D dibutuhkan untuk proses mineralisasi tulang sehingga dapat mencegah penurunan kepadatan tulang. ${ }^{1}$ Asupan protein yang berlebih diduga menghambat pembentukan tulang. Hasil penelitian menyatakan bahwa konsumsi protein tinggi menyebabkan hiperkalsiuria sehingga dapat meningkatkan risiko osteopenia dan osteoporosis. ${ }^{14}$

Berdasarkan penelitian yang dilakukan tahun 2010 menunjukan prevalensi osteoporosis sebesar $8.5 \%$ pada wanita usia $36-45$ di Sulawesi Barat, Jawa Barat, dan Yogyakarta. ${ }^{15}$ Tahun 2013 prevalensi obesitas wanita dewasa di Indonesia (>18 tahun) sebesar $32,9 \%$, naik $18,1 \%$ dari tahun $2007(14,8 \%)$. Prevalensi obesitas sentral adalah 26,6\%, lebih tinggi dari tahun $2007(18,8 \%) .{ }^{16}$ Prevalensi obesitas di kota Semarang pada tahun 2007 sebesar $21,1 \%$ dengan prevalensi pada wanita $(28,4 \%)$ lebih tinggi dibanding pada laki-laki $(7,2 \%){ }^{17}$

Mempertahankan kepadatan tulang yang optimal pada masa dewasa merupakan salah satu cara untuk mencegah osteoporosis di masa selanjutnya. Berdasarkan uraian di atas peneliti ingin meneliti hubungan lingkar pinggang dan kepadatan tulang wanita usia 30-50 tahun.

\section{METODE PENELITIAN}

Penelitian ini dilaksanakan di Kelurahan Bulustalan dan Kelurahan Sampangan Semarang pada Agustus dan September 2014. Penelitian ini termasuk dalam ruang lingkup keilmuan gizi masyarakat dengan desain penelitian crosssectional. Subyek dipilih berdasarkan kriteria inklusi, yaitu wanita dewasa usia 30-50 tahun, belum menopause, sedang tidak hamil, tidak menggunakan obat-obatan yang mempengaruhi kepadatan tulang, dan tidak memiliki kebiasaan merokok serta mengkonsumsi alkohol.

Berdasarkan perhitungan besar sampel diperoleh jumlah sampel minimal sebanyak 44 sampel. Variabel bebas dalam penelitian ini adalah lingkar pinggang, asupan protein, kalsium, dan vitamin D serta aktivitas fisik. Variabel terikat adalah kepadatan tulang.

Data lingkar pinggang diperoleh melalui hasil pengukuran panjang lingkar pinggang menggunakan metline dengan ketelitian $1 \mathrm{~mm}$. Data nilai kepadatan tulang diperoleh dari pengukuran dengan menggunakan alat bone densitometry metode Quantitative Ultrasound $(Q U S)$ yang dilakukan oleh petugas pemeriksaan tulang dengan mengukur tulang calcaneus (tumit). Kategori nilai kepadatan tulang antara lain normal (diatas -1 SD), osteopenia (-1 sampai -2,5 SD) dan osteoporosis (dibawah -2,5 SD). (18)

Asupan makanan berupa protein, kalsium, dan vitamin D diperoleh melalui formulir Food Frequency Semi Quantitative dengan melakukan wawancara. Hasil yang diperoleh kemudian diolah menggunakan program nutrisurvey. Data aktivitas 
fisik diperoleh dari kuesioner GPAQ (Global Physical Activity Questionnaire). Kuesioner GPAQ dikembangkan oleh World Health Organization yang terdiri dari 16 pertanyaan. Pertanyaan dalam kuesioner GPAQ dibagi dalam 3 domain yaitu domain aktivitas bekerja, aktivitas bepergian, dan aktivitas rekreasi. Hasil data aktivitas fisik dikategorikan menjadi aktivitas fisik rendah jika nilainya <600 MET.menit/minggu, aktivitas fisik sedang jika nilainya 600-1499 MET.menit/minggu, dan aktivitas fisik tinggi jika nilainya $\geq 1500$ MET.menit/minggu. MET atau metabolic equivalent merupakan rasio kecepatan metabolik kerja dengan kecepatan metabolik istirahat. Satu MET didefinisikan sebagai 1 $\mathrm{kkal} / \mathrm{kg} / \mathrm{jam}$.
Data diuji normalitasnya menggunakan uji kolmogorof-smirnov. Analisis hubungan antara lingkar pinggang, asupan protein, vitamin D dan aktivitas fisik dengan kepadatan tulang menggunakan uji rank Spearman. Sedangkan analisis hubungan antara asupan kalsium dengan kepadatan tulang menggunakan uji Pearson. Analisis multivariat dilakukan dengan uji regresi linier ganda untuk mengetahui variabel yang paling berpengaruh terhadap kepadatan tulang.

\section{HASIL PENELITIAN}

\section{Karakteristik Subyek Penelitian}

Subyek penelitian ini adalah 44 wanita usia 30-50 tahun dengan hasil penelitian sebagai berikut.

Tabel 1. Nilai Minimum, Maksimum, Rerata, Standar Deviasi Variabel Lingkar Pinggang, Kepadatan tulang, dan Aktivitas Fisik

\begin{tabular}{lcccc}
\hline \multicolumn{1}{c}{ Variabel } & Minimum & Maksimum & Rerata & Simpang Baku \\
\hline Lingkar pinggang (cm) & 68 & 106 & 87.80 & 10.43 \\
Kepadatan tulang (SD) & -2.4 & 0.4 & -0.79 & 0.69 \\
Aktivitas fisik (MET.menit/minggu) & 420 & 1740 & 994.09 & 373.45 \\
\hline
\end{tabular}

Kepadatan tulang subyek dalam penelitian ini berkisar antara -2,4 sampai 0.4. Subyek memiliki lingkar pinggang berkisar antara 68 sampai $106 \mathrm{~cm}$. Rerata aktivitas fisik subyek penelitian 994.09 MET.menit/minggu yang termasuk dalam kategori aktivitas fisik sedang (Tabel 1).

Tabel 2. Distribusi Frekuensi Kategori Kepadatan Tulang

\begin{tabular}{lcc}
\hline Kategori kepadatan tulang & Frekuensi \\
\cline { 2 - 3 } & $\mathbf{N}$ & \% \\
\hline Normal & 28 & 63.6 \\
Osteopenia & 16 & 36.4 \\
Jumlah & $\mathbf{4 4}$ & $\mathbf{1 0 0}$ \\
\hline
\end{tabular}

Sebagian besar kepadatan tulang subyek tergolong dalam kategori normal yaitu sebesar
$63.6 \%$ dan terdapat subyek yang mengalami osteopenia $36.4 \%$ (Tabel 2).

Tabel 3. Nilai Rerata Tingkat Kecukupan Protein, Kalsium, dan Vitamin D

\begin{tabular}{lcc}
\hline \multicolumn{1}{c}{ Variabel } & Rerata (\%) & Simpang Baku \\
\hline Tingkat kecukupan protein & 86.50 & 21.06 \\
Tingkat kecukupan kalsium & 50.60 & 23.26 \\
Tingkat kecukupan Vitamin D & 28.37 & 19.14 \\
\hline
\end{tabular}

Berdasarkan perhitungan kecukupan gizi individu, rerata tingkat kecukupan protein subyek penelitian sudah mencukupi kebutuhan protein perhari. Rerata tingkat kecukupan kalsium dan vitamin $\mathrm{D}$ subyek penelitian masih tergolong kurang (Tabel 3).
Hubungan Lingkar pinggang, Tingkat Kecukupan Protein, Kalsium, Vitamin D, dan Aktivitas Fisik dengan Kepadatan Tulang

Tabel 4 menunjukkan hasil uji bivariat antara lingkar pinggang, tingkat kecukupan protein, kalsium, vitamin $\mathrm{D}$ dan aktivitas fisik dengan kepadatan tulang. 
Tabel 4. Hubungan Lingkar Pinggang, Tingkat Kecukupan Protein, Kalsium, Vitamin D, dan Aktivitas Fisik dengan Kepadatan Tulang

\begin{tabular}{lcc}
\hline \multirow{2}{*}{ Variabel } & \multicolumn{2}{c}{ Kepadatan Tulang } \\
\cline { 2 - 3 } & $\mathrm{r}$ & $\mathrm{P}$ \\
\hline Lingkar Pinggang $^{\mathrm{a}}$ & -0.334 & $0.026^{*}$ \\
Aktivitas Fisik $^{\mathrm{a}}$ & 0.266 & 0.080 \\
Tingkat kecukupan Protein $^{\mathrm{a}}$ & 0.303 & $0.046^{*}$ \\
Tingkat kecukupan Kalsium $^{\mathrm{b}}$ & 0.314 & $0.038^{*}$ \\
Tingkat kecukupan Vitamin D $^{\mathrm{a}}$ & 0.232 & 0.129 \\
\hline
\end{tabular}

*Korelasi signifikan

${ }^{a}$ Uji rank Spearman

${ }^{\mathrm{b}} \mathrm{Uji}$ Pearson

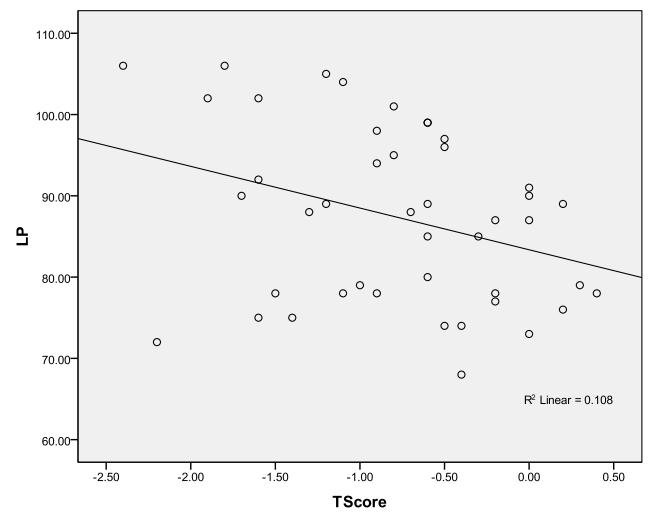

$\mathrm{p}=\mathbf{0 . 0 2 6}, \mathrm{r}=\mathbf{- 0 . 3 3 4}$

Gambar 1. Hubungan lingkar pinggang dengan kepadatan tulang.

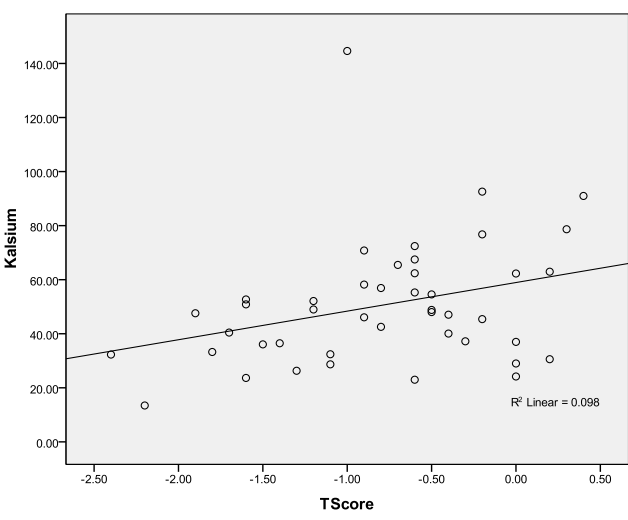

$\mathbf{p}=\mathbf{0 . 0 3 8}, \mathbf{r}=\mathbf{0 . 3 1 4}$

Gambar 2. Hubungan tingkat kecukupan kalsium dengan kepadatan tulang.

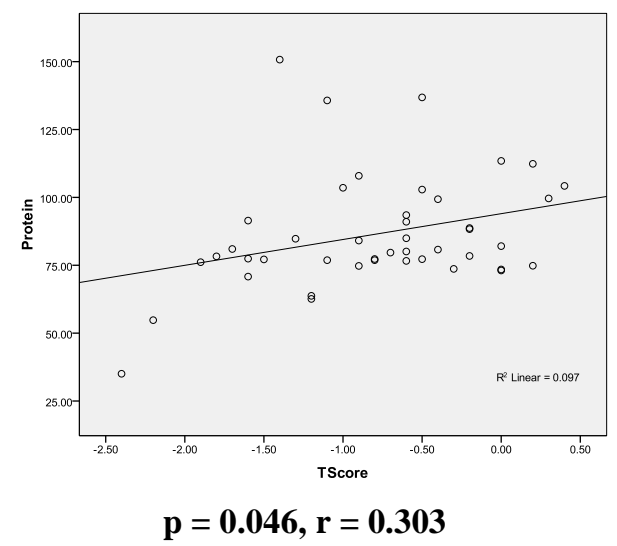

Gambar 3. Hubungan tingkat kecukupan protein dengan kepadatan tulang.

Berdasarkan hasil uji korelasi kalsium (0.038) dan tingkat kecukupan protein menunjukkan bahwa terdapat hubungan negatif dengan kepadatan tulang $(\mathrm{p}=0.046)$. Tidak terdapat yang bermakna antara lingkar pinggang dengan hubungan yang bermakna antara tingkat kepadatan tulang $(\mathrm{p}=0.026)$ dan terdapat hubungan kecukupan vitamin $\mathrm{D}$ dan aktivitas fisik dengan positif yang bermakna antara tingkat kecukupan kepadatan tulang $(\mathrm{p}>0.05)$.

Tabel 5. Hasil Uji Regresi Linier Ganda

\begin{tabular}{lcc}
\hline \multicolumn{1}{c}{ Variabel } & \multicolumn{2}{c}{ Kepadatan Tulang } \\
\cline { 2 - 3 } & B (Standardized Coefficient) & $\mathrm{p}$ \\
\hline Lingkar Pinggang $^{\mathrm{a}}$ & -0.257 & 0.075 \\
Aktivitas Fisik $^{\mathrm{a}}$ & 0.257 & 0.078 \\
Asupan Kalsium $^{\mathrm{b}}$ & 0.320 & 0.032 \\
\hline
\end{tabular}


Variabel-variabel tersebut dianalisis lebih lanjut menggunakan analisis regresi linier ganda $(\mathrm{p}<0.25)$ untuk mengetahui variabel yang paling berpengaruh terhadap kepadatan tulang. Hasil analisis regresi linier ganda menunjukkan variabel asupan kalsium yang paling mempengaruhi kepadatan tulang (Tabel 5).

\section{PEMBAHASAN}

Hasil penelitian pada 44 wanita usia 3050 tahun diketahui bahwa sebanyak 16 subyek (36.4\%) termasuk dalam kategori osteopenia dan tidak ada subyek dalam kategori osteoporosis. Hasil penelitian ini lebih rendah dari penelitian sebelumnya yang dilakukan di tiga provinsi di Indonesia tahun 2010 dengan prevalensi osteoporosis sebesar $8.5 \%$ pada wanita usia 3645 tahun. Penelitian tersebut dilakukan di provinsi Sulawesi Barat, Jawa Barat, dan Yogyakarta dengan jumlah subyek usia 36-45 tahun yang lebih banyak yaitu 554 subyek. ${ }^{15}$

Hasil penelitian ini menunjukan adanya hubungan negatif antara lingkar pinggang dengan kepadatan tulang pada wanita usia 30-50 tahun. Artinya peningkatan lingkar pinggang dapat menurunkan kepadatan tulang. Hasil penelitian ini sejalan dengan penelitian yang dilakukan di Puerto Rico pada wanita dan lakilaki usia 49-76 tahun yang juga menunjukan adanya hubungan negatif antara lemak abdominal dengan kepadatan. ${ }^{3}$ Penelitian lain dengan subyek laki-laki usia 40-59 tahun di Korea Selatan juga menyatakan bahwa kepadatan tulang berhubungan negatif dengan peningkatan rasio lingkar pinggang panggul. ${ }^{19}$

Hubungan lemak abdominal dengan penurunan kepadatan berkaitan dengan sitokin proinflamasi dan lemak viseral. ${ }^{20}$ Lemak viseral adalah lemak yang terdapat pada bagian intraabdominal di sekitar abdomen. ${ }^{6}$ Lemak viseral tersebut lebih banyak memproduksi sitokin proinflamasi dibanding lemak subkutan. ${ }^{21}$ Sitokin proinflamasi seperti TNF- $\alpha$, IL-1 dan IL-6 adalah mediator proses diferensiasi osteoklas dan penyerapan tulang. Sitokin proinflamasi tersebut dapat menstimulasi aktivitas osteoklas. IL-6 dan TNF- $\alpha$ berkaitan dengan kepadatan tulang yang rendah dan risiko patah tulang karena sitokin proinflamatori tersebut dapat meningkatkan aktivitas dan produksi osteoklas. ${ }^{8}$ Namun, jika dilihat dari usia subyek penelitian yang berusia 30-50 tahun sudah merupakan periode penurunan kepadatan tulang. Jika dikaitkan dengan usia subyek penelitian maka dimungkinkan juga dapat berpengaruh terhadap penurunan kepadatan tulang. ${ }^{22}$

Hasil penelitian menunjukan bahwa asupan kalsium memiliki hubungan positif dengan kepadatan tulang. Rerata tingkat kecukupan kalsium hanya $50.6 \%$ dari kebutuhan kalsium. Rata-rata asupan kalsium di Indonesia masih rendah, yaitu hanya sebesar 254 $\mathrm{mg} /$ hari. $^{23}$ Kalsium merupakan mineral pembentuk tulang utama yang harus tercukupi kebutuhannya untuk menjaga massa tulang, meminimalisir penurunan kepadatan tulang dan mengurangi risiko osteoporosis. ${ }^{24}$ Analisis yang dilakukan pada penelitian ini memperlihatkan hubungan yang positif dan signifikan antara asupan kalsium dengan kepadatan tulang.

Hasil penelitian juga menunjukan adanya hubungan positif yang bermakna antara tingkat kecukupan protein dengan kepadatan tulang. Artinya semakin tinggi tingkat kecukupan protein dapat meningkatkan kepadatan tulang. Data hasil penelitian untuk rata-rata jumlah asupan protein subyek penelitian sudah mencukupi kebutuhan protein perhari. Protein membantu menstimulasi pembentukan kolagen matriks tulang. Namun, asupan protein yang terlalu tinggi dapat mempengaruhi homeostasis kalsium dengan meningkatkan ekskresi kalsium melalui urin. Peningkatan ekskresi kalsium melalui urin dapat menyebabkan peningkatan resorpsi tulang sehingga meningkatkan risiko terjadinya osteopenia dan osteoporosis. ${ }^{14}$

Penelitian ini tidak terbukti bahwa asupan vitamin $\mathrm{D}$ berhubungan bermakna dengan kepadatan tulang, sehingga penelitian ini tidak berhasil membuktikan hipotesis yang ada. Hal ini kemungkinan disebabkan karena pemenuhan kebutuhan vitamin D tidak hanya didapat dari asupan makanan saja. Tubuh dapat mensintesis vitamin $\mathrm{D}$ dengan bantuan sinar matahari. ${ }^{25}$ Indonesia termasuk wilayah tropis yang banyak mendapat paparan sinar matahari, sehingga kebutuhan vitamin D banyak didapatkan melalui paparan sinar matahari. ${ }^{26}$ Selain itu, penelitian ini menggunakan desain cross sectional sehingga dimungkinkan tidak dapat membuktikan hubungan antara asupan vitamin D dengan kepadatan tulang pada wanita usia 3050 tahun. Rerata tingkat kecukupan asupan vitamin D subyek penelitian masih kurang dari kebutuhan. Ketidakcukupan asupan vitamin D berhubungan dengan penuruanan absorpsi kalsium dan peningkatan produksi hormon paratioid (PTH). Apabila absorpsi kalsium 
dalam usus menurun maka hormon paratiroid akan meningkatkan mobilisasi kalsium yang tersimpan dalam tulang dan meningkatkan reabsorpsi kalsium pada ginjal. ${ }^{1}$

Hasil penelitian juga tidak menunjukan adanya hubungan yang bermakna antara aktivitas fisik dengan kepadatan tulang. Hasil ini tidak sejalan dengan penelitian sebelumnya menyatakan bahwa tingkat aktivitas fisik yang tinggi baik untuk kesehatan tulang pada wanita premenopause. ${ }^{13}$ Penelitian lain yang dilakukan dengan rancangan studi meta-analysis control trial juga menunjukan hubungan positif antara olahraga dengan kepadatan tulang wanita premenopause. ${ }^{27}$ Perbedaan hasil penelitian dapat disebabkan karena perbedaan metode penelitian, dimana pada penelitian ini menggunakan rancangan penelitian cross sectional sehingga belum dapat membuktikan hubungan aktivitas fisik dan kepadatan tulang. Aktivitas fisik memiliki peran penting dalam mencegah penurunan kepadatan tulang terkait penuaan karena adanya beban mekanik. Beban mekanik yang timbul saat beraktivitas menyebabkan tulang beradaptasi dengan mengoptimalkan kekuatan dan arsitektur tulang. Kekuatan dan ketahanan tulang akan meningkat seiring dengan peningkatan beban mekanik. ${ }^{28}$ Mekanisme hubungan aktivitas fisik dan tulang diketahui melibatkan osteosit yang akan mendeteksi beban mekanik tersebut dan mentrasduksi ke osteoklas dan osteoblas sehingga meningkatkan pembentukan sel tulang. Pada tingkat sel, aktivitas fisik akan mengurangi sekresi sklerostin oleh osteosit yang akan meningkatkan pembentukan osteoblas. ${ }^{27}$

\section{SIMPULAN}

Terdapat hubungan negatif dan signifikan antara lingkar pinggang dengan kepadatan tulang dan terdapat hubungan positif dan signifikan antara asupan kalsium dengan kepadatan tulang pada wanita usia 30-50 tahun. Dalam penelitian ini tidak terbukti terdapat hubungan antara asupan protein, vitamin D dan aktivitas fisik dengan kepadatan tulang.

\section{SARAN}

Wanita usia 30-50 perlu memperhatikan status gizi, memperhatikan kualitas asupan zat gizi, dan memperbanyak aktivitas fisik, khususnya olahraga agar dapat mempertahankan dan menjaga kepadatan tulang untuk menghindari terjadinya osteoporosis di kemudian hari.

\section{UCAPAN TERIMAKASIH}

Terima kasih penulis sampaikan kepada responden, enumerator, dan Team Bone Scan Anlene atas kerjasama dan partisipasinya dalam penelitian ini.

\section{DAFTAR PUSTAKA}

1. Mahan K, Escott SS. Krause's Food, Nutrition And Diet Theraphy. $13^{\text {th }}$ Edition. Philadelphia : Saunders; 2012.

2. World Health Organization. Prevention and management of osteoporosis. Geneva: World Health Organization, 2003

3. Shilpa NB, Bess DH, Marian TH, Alice HL, and Katherine LT. Centrally located body fat is associated with lower bone mineral density in older Puerto Rican adults. Am J Clin Nutr 2011;94:1063-70.

4. Ismael FF, Jefferson RC, Diego GD, Jamile SC, Augusto CF, Romulo AF. The relationship between visceral fat thickness and bone mineral density in sedentary obese children and adolescents. BMC Pediatrics 2013, 13:37, Vol. 13. 1471-2431.

5. Russell M, Mendes N, Miller K, Rosen CJ, Lee H, Klibanski A, et al. Visceral Fat Is a Negative Predictor of Bone Density Measures in Obese Adolescent Girls. J Clin Endocrinol Metab, March 2010, 95(3):1247-1255

6. Whitney E, Rolfes SR. Understanding Nutrition. $12^{\text {th }}$ ed. Belmont: Wadsworth, Cengage Learning; 2011.

7. Rosario $M$ dan Isabel A. Chronic inflammation in obesity and metabolic syndrome. Mediators of Inflammation, 2010.

8. Cao JJ. Effects of obesity on bone metabolism. Journal of Orthopaedic Surgery and Research 2011, 6:30

9. Ganesan K, Teklehaimanot S, Tran TH, Asuncion M, dan Keith N. Relationship of C-Reactive Protein and bone mineral density in community-dwelling elderly. Journal of The National Medical Association, 2005.

10. Forouhi NG, Sattar N, dan McKeigue PM. Relation of C-reactive protein to body fat distribution and features of the metabolic syndrome in Europeans and South Asians. International Journal of Obesity (2001) 25, 1327-1331

11. Park KG, Park KS, Kim MJ, Kim HS, Suh YS, Ahn JD, et al. Relationship between serum adiponectin and leptin concentrations 
and body fat distribution. Diabetes Research and Clinical Practice 63 (2004) 135-142.

12. Bao Y, Ma X, Yang R, Wang F, Hao Y, Dou J, et al. Inverse Relationship between Serum Osteocalcin Levels and Visceral Fat Area in Chinese Men. J Clin Endocrinol Metab, 2013:98: 345-351.

13. Saravi F, Sayegh F. Bone mineral density and body composition of adult premenopausal women with three levels of physical acticity. Journal of Osteoporosis 2013;1-7.

14. Heaney RP and Layman DK. Amount and type of protein influences bone health. Am J Clin Nutr. 2008;87(5):1567S-1570S.

15. Prihatini S, Mahirawati VK, Jahari AB, Sudirman H. Faktor determinan osteoporosis di tiga provinsi di Indonesia. Media Litbang Kesehatan 2010; 20(2):9199

16. Badan Penelitian dan Pengembangan Kesehatan. Riset Kesehatan Dasar 2013. Jakarta: Departemen Kesehatan RI, 2013.

17. Badan Penelitian dan Pengembangan Kesehatan. Riset Kesehatan Dasar 2007: Jakarta: Departemen Kesehatan RI, 2008.

18. Department of Health and Human Service. Bone health and osteoporosis: a report of the surgeon general. Washington: office of the surgeon general,2004.

19. Seo HJ,Kim SG, Kim CS. Risk factors for bone mineral density at the calcaneus in 40-59 year-old male workers: A crosssectional study in Korea. BMC Public Health 2008, 8:253

20. Sheu Y,Chauley JA. The Role of Bone Marrow and Visceral Fat on Bone Metabolism. Curr Osteoporos Rep 2011;9:67-75

21. Cauley JA, Danielson ME, Boudreau $\underline{\text { RM}}$, Forrest KY, Zmuda JM, Pahor M, et al. Inflammatory markers and incident fracture risk in older men and women: the Health Aging and Body Composition Study 2007;22(7):1088-1095

22. Department of Health and Human Service. The surgeon's general report on bone health and osteoporosis: what it mean to you. Washington: office of the surgeon general, 2012.

23. Departemen Kesehatan RI. Pedoman pengendalian osteoporosis. Jakarta: Kementerian Kesehatan Republik Indonesia, 2008.
24. Nelms M, Sucher KP, Lacey K, and Roth SL. Nutrition Therapy and pathophisiology. $2^{\text {nd }}$ ed. Belmont : Wadsworth, Cengage Learning; 2011.

25. Prentice A,Goldberg GR, Schoenmaker I. Vitamin D across the lifecycle: physiology and biomarkers. Am J Clin Nutr 2008;88(suppl):500S-6S

26. Almatsier S. Prinsip Dasar Ilmu Gizi. Jakarta: PT Gramedia, 2006.

27. Kelley GA, Kelley KS, Kohrt WM. Exercise and bone mineral density in premenopausal women: a meta-analysis of randomized controlled trials. International Journal of Endocrinology, 2013;2013:1-16.

28. Nilsson M. The role of physical activity on bone density and bone geometry in men [skripsi].Sweden : University of Gothenburg. 2010 